\title{
Untreated wastewater as a source of carbapenem-resistant bacteria to the riverine ecosystem
}

\author{
Jasna Hrenovic ${ }^{1 *}+$, Goran Durn ${ }^{2 *}+$, Snjezana Kazazic ${ }^{3}$, Svjetlana Dekic' and Martina Seruga Music \\ 'University of Zagreb, Faculty of Science, Zagreb, Croatia \\ 2University of Zagreb, Faculty of Mining, Geology and Petroleum Engineering, Zagreb, Croatia \\ ${ }^{3}$ Ruđer Boskovic Institute, Division of Physical Chemistry, Zagreb, Croatia
}

\begin{abstract}
Bacteriological pollution, especially that including clinically important bacteria, of the aquatic environment caused by anthropogenic pressure attracts much attention with regard to public health. Reports to date have not addressed the concentration of emerging carbapenem-resistant bacteria (CRB) in riverine ecosystems, and the source of this pollution is hard to track. We examined the impact of discharge of untreated wastewaters on the bacterial population in the riverine ecosystem, with emphasis on clinically important CRB using a small river in Croatia as a model. River sediments were analysed mineralogically and geochemically. Cultivation of CRB was performed at 37 and $42^{\circ} \mathrm{C}$ to distinguish the presumably environmental intrinsically resistant (CRB37) from the presumably clinically important acquired resistance (CRB42) species. The significantly positive correlation of CRB42 with CRB37 and total heterotrophs, but not with intestinal enterococci, suggests that entry of CRB42 in riverine ecosystem is not necessarily connected to faecal pollution. The numbers and prevalence of CRB42 are rather dependent on the type of pollution, and is connected to the discharge of wastewaters from different human and animal healthcare centres. Emerging hospital pathogens Acinetobacter baumannii and Klebsiella pneumoniae were exclusively isolated among CRB42 from river water after the discharge of wastewater of a general hospital. The CRB42, once discharged into the riverine ecosystem, behaves as part of the indigenous bacterial population, and could be spread through the natural water bodies or accumulate in river sediments. This implies the need for disinfection of hospital wastewater prior to its discharge into the natural environment in order to avoid the consequent public-health threat. The anthropogenic impact evidenced as bacteriological changes is accompanied by an increase in heavy metal concentrations in river sediments.
\end{abstract}

Keywords: bacteria, carbapenems, water, sediment, environment

\section{INTRODUCTION}

Water is the most important resource on the planet. With the constant growth and increasing needs of human populations, aquatic environments are under anthropogenic pressure. Wastewaters from industry and agriculture, together with hospital and domestic wastewaters, as well as changes in hydrogeomorphology, contribute to the contamination and degradation of aquatic environments (Lenart-Boroń et al., 2017). Some contaminants (solids, chemicals, microorganisms) are removed from sewage by wastewater treatment plants with varying efficiency. Moreover, not all wastewater is treated before discharge into the natural environment. Contamination of water bodies is dependent on the amount, type and degradation potential of contaminants, and the self-purification ability of the recipient waterbody (Ostroumov, 2006).

Human and animal pathogens are considered to be important water contaminants. Efficient microbial indicators of anthropogenic pressure are total coliforms, faecal coliforms, Escherichia coli and intestinal enterococci, as their populations are proportional to the amount of faeces deposited into the environment (Ashbolt et al., 2001; Páll et al., 2013). Furthermore, clinically important bacteria in aquatic environments that are resistant to multiple frequently used antibiotics are also of great importance. These bacteria could propagate the resistance genes in aquatic environments and

\footnotetext{
* To whom all correspondence should be addressed. e-mail: jasna.hrenovic@biol.pmf.hr

$\dagger$ Both authors contributed equally to the manuscript.

Received 30 January 2018, accepted in revised form 4 December 2018.
}

cause community-acquired infections in both humans and animals (Dexter et al., 2015; Marathe et al., 2017).

Carbapenems are broad range $\beta$-lactam antibiotics used as a last resort in treating infections with multi-drug resistant bacteria. In the past few decades, the emergence of strains resistant to carbapenems has been a growing concern (Meletis, 2016). In February 2017, the World Health organization (WHO) published a list of the most dangerous pathogens for human health. At the top of that list are carbapenem-resistant Acinetobacter baumannii, Pseudomonas aeruginosa and Enterobacteriaceae (WHO, 2017). In Croatia, carbapenem resistance of A. baumannii has increased from $10 \%$ in 2008 to $86 \%$ in 2016 (CAMS 2017). There have been several reports of bacteria with acquired carbapenem resistance isolated from hospital wastewaters (Ferreira et al., 2011; Zhang et al., 2012; Zhang et al., 2013; Chandran et al., 2014; Seruga Music et al., 2017), as well as raw and secondary treated municipal wastewaters (Hrenovic et al., 2016; Hrenovic et al., 2017a,b). Regarding the natural aquatic environment, in the Danube River during the Joint Danube Survey 3 in 2013 one carbapenem-resistant Klebsiella pneumoniae and two other Enterobacteriaceae were reported (Kittinger et al., 2016). Additionally, one carbapenem-resistant isolate of A. baumannii was found in the Seine River (Gihrlich et al., 2010) and four in the Sava River (Seruga Music et al., 2017). There have also been reports of carbapenem-resistant Enterobacteriaceae from rivers in the United States (Aubron et al., 2005), Tunisia (Chouchani et al., 2013), Switzerland (Zurfluh et al., 2013), Portugal (Kieffer et al., 2016), India (Akiba et al., 2016), and Spain (Piedra-Carrasco et al., 2017). These reports point to the growing occurrence of clinically 
important bacteria with acquired resistance to carbapenems in the aquatic environment. However, all of these studies report the finding of one or several isolates, and there are no data regarding the concentration of clinically important carbapenem-resistant bacteria in riverine ecosystems. Furthermore, studies demonstrating the anthropogenic impact on the riverine ecosystem in general have lacked information on the origin of the pollution.

The aim of this study was to examine the anthropogenic impact on the viable bacterial population in the riverine ecosystem with emphasis on clinically important carbapenem-resistant bacteria using a small river as a model. The anthropogenic impact was additionally followed by mineralogical and geochemical analyses of river sediment.

\section{MATERIALS AND METHODS}

\section{Site location and sampling}

The examined area of the Krapinica and Krapina Rivers is shown in Fig. 1. Stations 1-3 represent the flow of Krapinica River, while Stations 4 and 5 were chosen to examine the
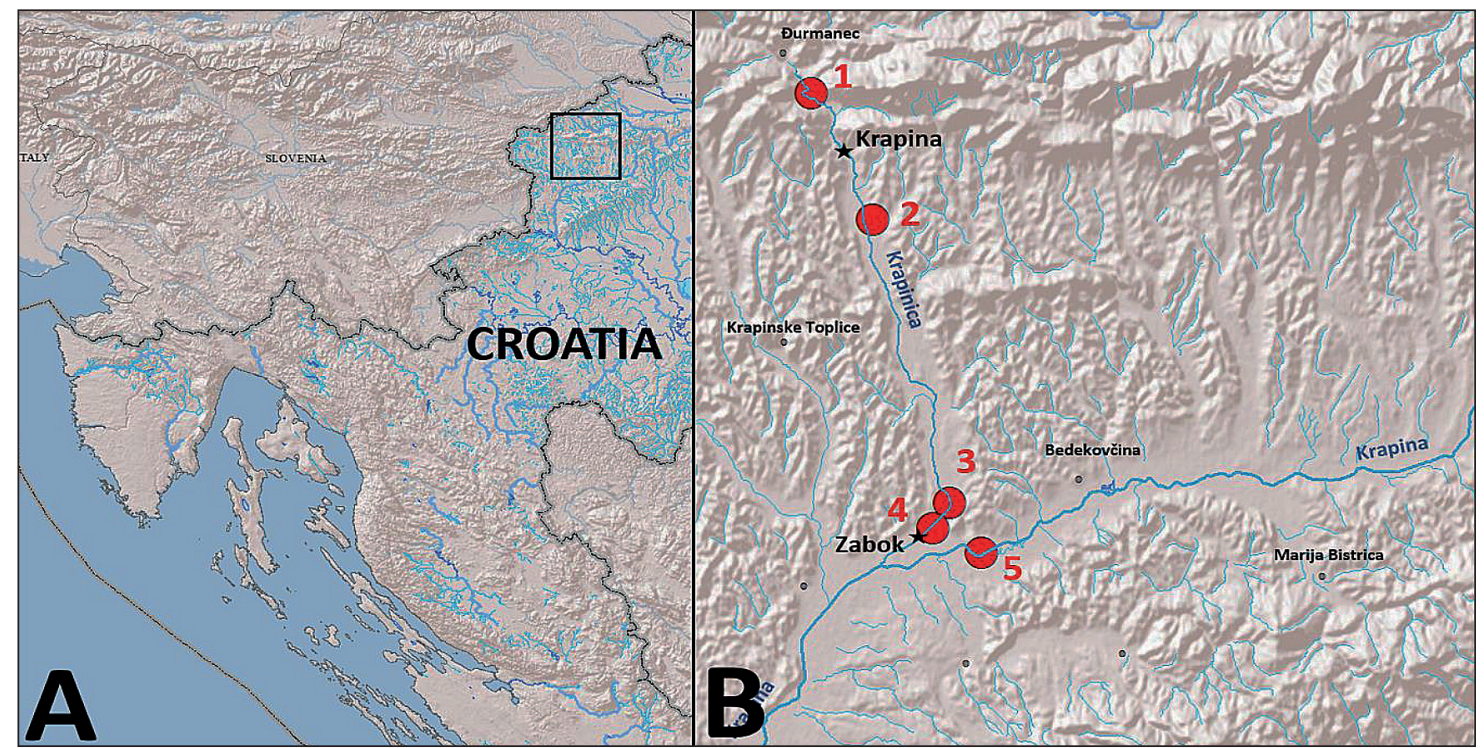

Figure 1

Location of the study site in Croatia (A, black rectangle) and position of sampling stations (B). For explanation see Table 1.
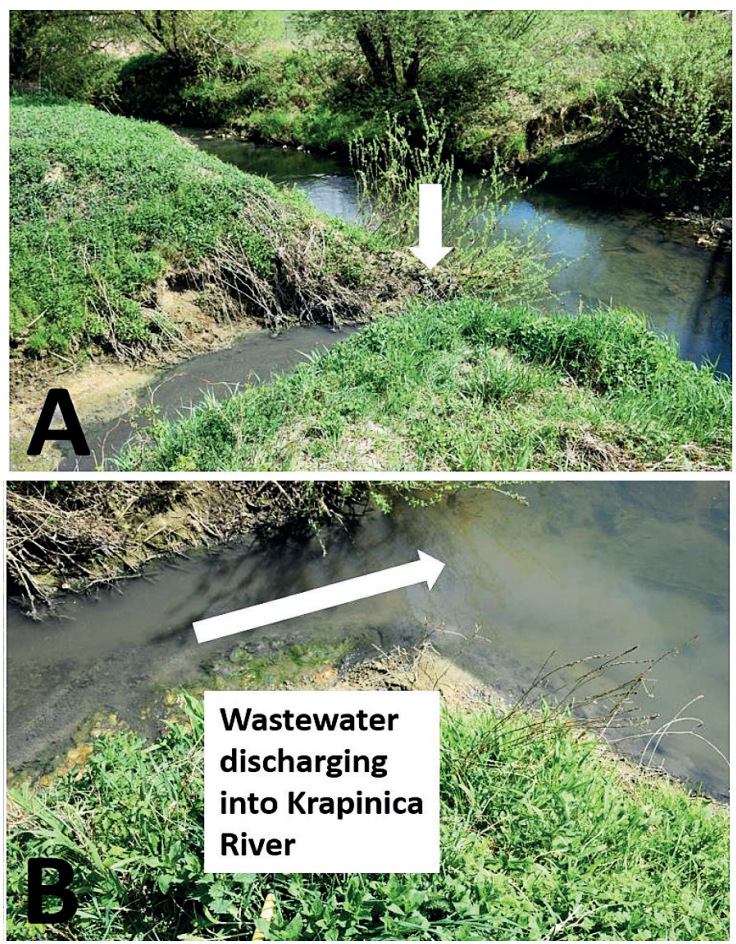

\section{Figure 2}

The mouth of Zabok Creek in the Krapinica River (north of Sampling Station 4). White arrow (A) points to the position of the discharge site (B).
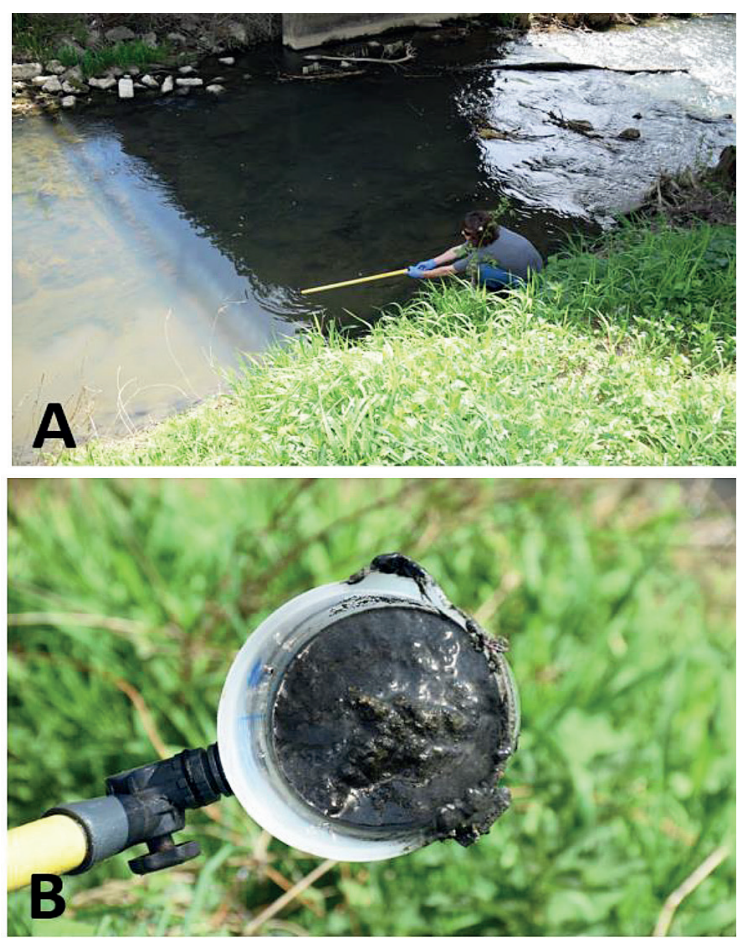

Figure 3

Sampling of water (A) and sediment (B) at Sampling Station 4 


\begin{tabular}{|c|l|c|}
\hline \multicolumn{2}{|c|}{ LABLE 1 } \\
\hline \multirow{2}{*}{ Station number } & Description & $\begin{array}{c}\text { pH } \\
\text { value }\end{array}$ \\
\hline \multirow{2}{*}{1} & Water, upstream of town Krapina, village (1 000 residents) & 7.76 \\
\cline { 2 - 3 } & Sediment, upstream of town Krapina & 7.27 \\
\hline \multirow{2}{*}{2} & Water, downstream of town Krapina (12 500 residents), 5 primary care stations and veterinary station & 7.57 \\
\cline { 2 - 3 } & Sediment, downstream of town Krapina, 5 primary care stations and veterinary station & 6.88 \\
\hline \multirow{2}{*}{3} & Water, upstream of town Zabok, rehabilitation hospital & 7.62 \\
\cline { 2 - 4 } & Sediment, upstream of town Zabok, rehabilitation hospital & 6.96 \\
\hline \multirow{2}{*}{4} & Water, downstream of town Zabok (9 000 residents), primary care station and veterinary station & 7.62 \\
\cline { 2 - 4 } & Sediment, downstream of town Zabok, primary care station and veterinary station & 6.05 \\
\hline \multirow{2}{*}{5} & Water, downstream of Zabok General Hospital & 7.72 \\
\cline { 2 - 3 } & Sediment, downstream of Zabok General Hospital & 6.69 \\
\hline
\end{tabular}

separate input of urban (Zabok creek, Fig. 2) and hospital wastewater (Krapina River) on the ecosystem. In total, 5 samples of water and 5 samples of corresponding sediment were collected along the Krapinica and Krapina Rivers (Table 1). It is very common and constant in this region of Croatia to have untreated sewage released directly into the riverine ecosystem. Based on the distribution of settlements, all sampling locations were in the proximity of untreated sewage release points. Raw wastewaters entering the river consist of domestic wastewaters at Station 1, but at Stations 2-5, in addition the wastewaters from different human and animal healthcare centres (primary care and veterinary stations, rehabilitation and general hospital) are discharged.

For bacteriological analyses the water and river sediment samples were taken aseptically (Fig. 3) in sterile plastic bottles and processed in the laboratory within $4 \mathrm{~h}$ after collection. The $\mathrm{pH}$ value of water was measured in the original samples, while $\mathrm{pH}$ value of sediment was measured after suspension (1:2.5) of sediment in distilled water.

\section{River sediment analyses}

River sediments were sieved through a $2 \mathrm{~mm}$ sieve and the fraction $<2 \mathrm{~mm}$ was prepared for analyses. In general, the $\geq 2 \mathrm{~mm}$ fraction (gravel) was less than $5 \mathrm{wt} \%$. Particle size distribution was determined by pipette-method, with wet sieving and sedimentation after dispersion with sodiumpyrophosphate $\left(\mathrm{Na}_{4} \mathrm{P}_{2} \mathrm{O}_{7}, c=0.4 \mathrm{M}\right)$. The chemical composition (fraction $<2 \mathrm{~mm}$ ) was determined by the commercial ACME Analytical Laboratory, Canada. Major oxides and several minor elements were determined by ICP-emission spectrometry following a lithium metaborate/tetraborate fusion and dilute nitric digestion. Refractory elements were determined by ICP mass spectrometry following a lithium metaborate/tetraborate fusion and nitric acid digestion. The mineral composition of $<2 \mathrm{~mm}$ and $<2 \mu \mathrm{m}$ fractions of original samples (and samples after the carbonate mineral phases were removed) was determined by X-ray powder diffraction (XRD) using a Philips diffractometer (graphite monochromator, $\mathrm{CuK} \mu$ radiation, proportional counter). To remove carbonates, samples were treated with a $1 \mathrm{M}$ $\mathrm{NaOAc}$ solution buffered at pH 5 with HOAc (Jackson, 1979; Tassier et al., 1979). The $<2 \mu \mathrm{m}$ fraction was separated by sedimentation in cylinders and quantitatively obtained after the appropriate settling time. The XRD patterns of clay fraction (non-oriented and oriented preparations) were obtained after the following treatments: air drying; Mg-saturation; K-saturation; K-saturation and ethylene glycol solvation; K-saturation and DMSO solvation; Mg-saturation and ethylene glycol solvation; and heating for $2 \mathrm{~h}$ at 350 and $550^{\circ} \mathrm{C}$ after $\mathrm{K}$ and $\mathrm{Mg}$ saturation. The identification of clay minerals was based on the methods outlined by Brindley and Brown (1980) and Moore and Reynolds (1989). The term 'illitic material' was used as defined by Środoń (1984) and Środoń and Eberl (1984). Semi-quantitative estimates of minerals were based on the relative intensities of characteristic X-ray peaks.

\section{Bacteriological analyses}

The water and sediment samples were analysed in triplicate after its suspension and dilution in sterile peptone water. Aerobically grown total heterotrophic bacteria were determined on Nutrient agar (Biolife) after incubation at $22^{\circ} \mathrm{C} / 72 \mathrm{~h}$ (APHA et al., 2005). The intestinal enterococci were determined according to HRN ISO 7899-2 (2000). Membrane filters were incubated on Slanetz Bartley agar (Biolife) at $37^{\circ} \mathrm{C} / 72 \mathrm{~h}$ and subsequent confirmation of intestinal enterococci was done on Bile esculin azide agar (Sigma-Aldrich) after incubation at $44^{\circ} \mathrm{C} / 4 \mathrm{~h}$. Carbapenem-resistant bacteria were determined on CHROMagar Acinetobacter supplemented with CR102 (CHROMagar), intended for the cultivation of clinically relevant carbapenem-resistant bacteria, after incubation at both $37^{\circ} \mathrm{C} / 72 \mathrm{~h}$ and $42^{\circ} \mathrm{C} / 48 \mathrm{~h}$ (CRB37 and CRB42, respectively). Cultivation of carbapenem-resistant bacteria was performed at $42^{\circ} \mathrm{C}$ to suppress the growth of environmental autochthonous species with intrinsic resistance to carbapenems, which grows only at $37^{\circ} \mathrm{C}$ (Hrenovic et al., 2016; Hrenovic et al., 2017a,b). The numbers of total heterotrophic bacteria, intestinal enterococci and carbapenem-resistant bacteria were determined as colony forming units (CFU), logarithmically transformed, and expressed as log CFU per $1 \mathrm{~mL}$ of water or $1 \mathrm{~g}$ of wet sediment.

The prevalence of carbapenem-resistant bacteria among total heterotrophic bacteria was calculated as a percentage ratio of absolute numbers $\left(\mathrm{CFU}_{\mathrm{CRB}} / \mathrm{CFU}_{\text {heterotrophic }}\right) \times 100$. The correlations between variables were estimated with Spearman's rank correlation by the Statistica 13 software (StatSoft, Inc., Tulsa, USA). A $p$-value of $<0.05$ was considered significant. 


\section{Identification and characterization of carbapenem- resistant bacteria}

Identification of morphologically different colonies from plates intended for cultivation of CRB grown at $37^{\circ} \mathrm{C}$ and $42^{\circ} \mathrm{C}$ was performed by routine bacteriological techniques and matrix-assisted laser desorption ionization-time of flight mass spectrometry - MALDI-TOF MS (software version 3.0, Microflex LT, Bruker Daltonics) on cell extracts (Sousa et al., 2014). For the carbapenem-resistant bacteria from critical list of WHO (2107) (A. baumannii and Enterobacteriaceae) the confirmation of resistance to carbapenems (meropenem, imipenem) was performed. The antibiotic susceptibility was firstly assessed by disk diffusion method and confirmed according to MICs values obtained by Vitek2 system (Biomerieux). MICs values were interpreted according to EUCAST breakpoints (2017). In order to assess the genetic relationship of A. baumannii isolate with described clinical and environmental isolates the multi-locus sequence typing (MLST) of fragments of 7 traditional housekeeping genes ( $g l t A, g y r B, g d h B, r e c A, c p n 60, g p i$ and $r p o D$ ) were performed (Seruga Music et al., 2017). The sequence type (ST) was retrieved from the A. baumannii MLST website (http://pubmlst.org/abaumannii/).

\section{RESULTS}

\section{Grain size, geochemistry and mineral composition of} river sediments

River sediments from 5 sampling locations were analysed. Samples from Stations 1, 2 and 3 are composed dominantly of sand sized particles and represent sand, sandy loam and loamy sand, respectively (Fig. 4, Soil Science Division Staff, 2017). Samples from Stations 4 and 5 contain a higher amount of silt and clay than sand sized particles and represent loams (Fig. 4). Higher content of silt and clay fraction is accompanied

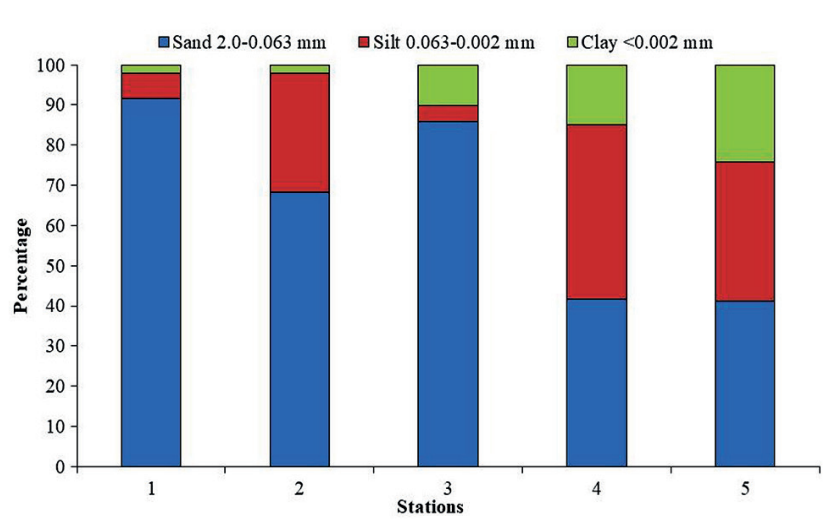

Figure 4

Particle size distribution of the investigated sediments

by higher LOI, content of $\mathrm{Al}_{2} \mathrm{O}_{3}, \mathrm{Fe}_{2} \mathrm{O}_{3}, \mathrm{MgO}, \mathrm{Na}_{2} \mathrm{O}, \mathrm{K}_{2} \mathrm{O}$ and $\mathrm{TiO}_{2}$, but lower content of $\mathrm{SiO}_{2}$ as compared to sand-enriched samples (Table 2). Samples containing a higher content of silt and clay fraction are also enriched in $\mathrm{As}, \mathrm{Ba}, \mathrm{Cd}, \mathrm{Co}, \mathrm{Cs}, \mathrm{Cu}$, $\mathrm{Hg}, \mathrm{Mo}, \mathrm{Ni}, \mathrm{Pb}, \mathrm{Ta}, \mathrm{U}, \mathrm{V}$ and $\mathrm{Zn}$ (Table 3). This indicates that silt and clay fractions of analysed sediments are probably the main scavengers of heavy metals (Salomons and Förstner, 1984). Analyses of $<2 \mathrm{~mm}$ and $<2 \mu \mathrm{m}$ fractions showed that all samples are composed of quartz as the predominant mineral phase, following calcite, dolomite, plagioclase, $\mathrm{K}$-feldspar, goethite, micaceous clay minerals (mica and illitic material), kaolinites, mixed-layer clay minerals, while 14 Á clay minerals (smectite and/or vermiculite) and XRD-amorphous compounds are detected only in the clay fraction of Samples 3-5. Although the decrease in particle size of downstream sediments is a natural phenomenon, the increased LOI, heavy metal concentration and both 14 Á clay minerals and amorphous matter contents suggest that Sediment Samples 4 and 5 are under high anthropogenic pressure.

\begin{tabular}{|c|c|c|c|c|c|c|c|c|c|c|c|}
\hline \multicolumn{10}{|c|}{ Chemical composition (in wt\%) of the investigated sediments } \\
\hline Station number & $\mathrm{SiO}_{2}$ & $\mathrm{Al}_{2} \mathrm{O}_{3}$ & $\mathrm{Fe}_{2} \mathrm{O}_{3}$ & $\mathrm{MgO}$ & $\mathrm{CaO}$ & $\mathrm{Na}_{2} \mathrm{O}$ & $\mathrm{K}_{2} \mathrm{O}$ & $\mathrm{TiO}_{2}$ & $\mathrm{P}_{2} \mathrm{O}_{5}$ & LOI $^{\text {a }}$ & Sum \\
\hline 1 & 84.11 & 3.98 & 2.03 & 0.86 & 2.95 & 0.56 & 1.20 & 0.13 & 0.06 & 4.1 & 99.98 \\
\hline 2 & 85.61 & 3.94 & 1.69 & 1.04 & 2.11 & 0.56 & 1.25 & 0.15 & 0.06 & 3.5 & 99.91 \\
\hline 3 & 80.19 & 5.06 & 2.85 & 0.93 & 2.11 & 0.60 & 1.30 & 0.23 & 0.15 & 6.5 & 99.92 \\
\hline 4 & 65.17 & 10.33 & 4.55 & 2.14 & 3.24 & 0.86 & 1.94 & 0.57 & 0.28 & 10.7 & 99.78 \\
\hline 5 & 67.71 & 12.42 & 4.84 & 1.56 & 2.00 & 1.03 & 1.89 & 0.86 & 0.13 & 7.2 & 99.64 \\
\hline
\end{tabular}

aloss on ignition $\left(1000^{\circ} \mathrm{C}\right)$.

TABLE 3

Content of sulfur and selected trace elements in the investigated sediments

\begin{tabular}{|c|c|c|c|c|c|c|c|c|c|c|c|c|c|c|c|}
\hline Station number & S & As & Ba & Cd & Co & Cs & Cu & Hg & Mo & Ni & Pb & Ta & U & V & Zn \\
\hline 1 & 0.02 & 3.1 & 188 & $<0.1$ & 3.5 & 1.1 & 3.2 & 0.08 & 0.2 & 5.8 & 5.6 & 0.2 & 0.8 & 16 & 21 \\
\hline 2 & 0.04 & 1.8 & 182 & $<0.1$ & 3.2 & 1.1 & 4.9 & 0.16 & 0.1 & 6.5 & 12.1 & 0.3 & 0.7 & 17 & 26 \\
\hline 3 & 0.08 & 9.3 & 229 & $<0.1$ & 6.7 & 1.8 & 11.3 & 0.07 & 0.3 & 12.7 & 16.4 & 0.3 & 1.1 & 26 & 41 \\
\hline 4 & 0.08 & 7.2 & 336 & 0.2 & 11.1 & 4.4 & 29.5 & 0.34 & 0.4 & 27.7 & 24.5 & 0.7 & 2.0 & 71 & 83 \\
\hline 5 & $<0.02$ & 9.3 & 380 & 0.3 & 15.4 & 4.9 & 23.4 & 0.11 & 0.5 & 39.8 & 16.3 & 1.1 & 2.6 & 95 & 65 \\
\hline
\end{tabular}

S in $w t \%$, As to $\mathrm{Zn}$ in $p p m$ 


\section{Bacteriological analyses}

The $\mathrm{pH}$ values of water and sediment samples averaged 7.34, with a significant drop for sediment at Station 4 (Table 1). However, all $\mathrm{pH}$ values were within the range that supports the survival of neutrophilic bacteria. Numbers of bacteria in river water and sediment at 5 stations along the river are shown in Fig. 5. Bacterial counts at all stations were generally present in descending order: total heterotrophs, intestinal enterococci, CBR37, and CRB42. The numbers of all monitored bacteria were higher in sediment as compared to the corresponding water sample. The numbers of total heterotrophic bacteria and intestinal enterococci averaged $6.7 \pm 0.9$ and $2.2 \pm 1.1 \mathrm{log}$
CFU per $1 \mathrm{~mL}$ of water or $1 \mathrm{~g}$ of wet sediment, respectively, in all analysed samples. A substantial increase with increasing distance downstream (Stations 1-3) was evidenced only for CRB42 (Fig. 5), i.e., no CRB42 were isolated at Station 1 (detection limit $50 \mathrm{~mL}$ of water or $1 \mathrm{~g}$ of sediment), while they were present at Stations 2 and 3. The highest increase of both CBR37 and CRB42 was evidenced in sediment at Stations 4 and 5 , which receive the input of urban and hospital wastewater. The prevalence of CRB37 ranged from $0.0002-0.001 \%$ in water and $0.001-1.1 \%$ in sediment samples. The prevalence of CRB42 was lower and averaged from $0-0.0001 \%$ in water and $0-0.001 \%$ in sediment samples (Fig. 5). The prevalence as well as the absolute numbers of CRB42 were always lower

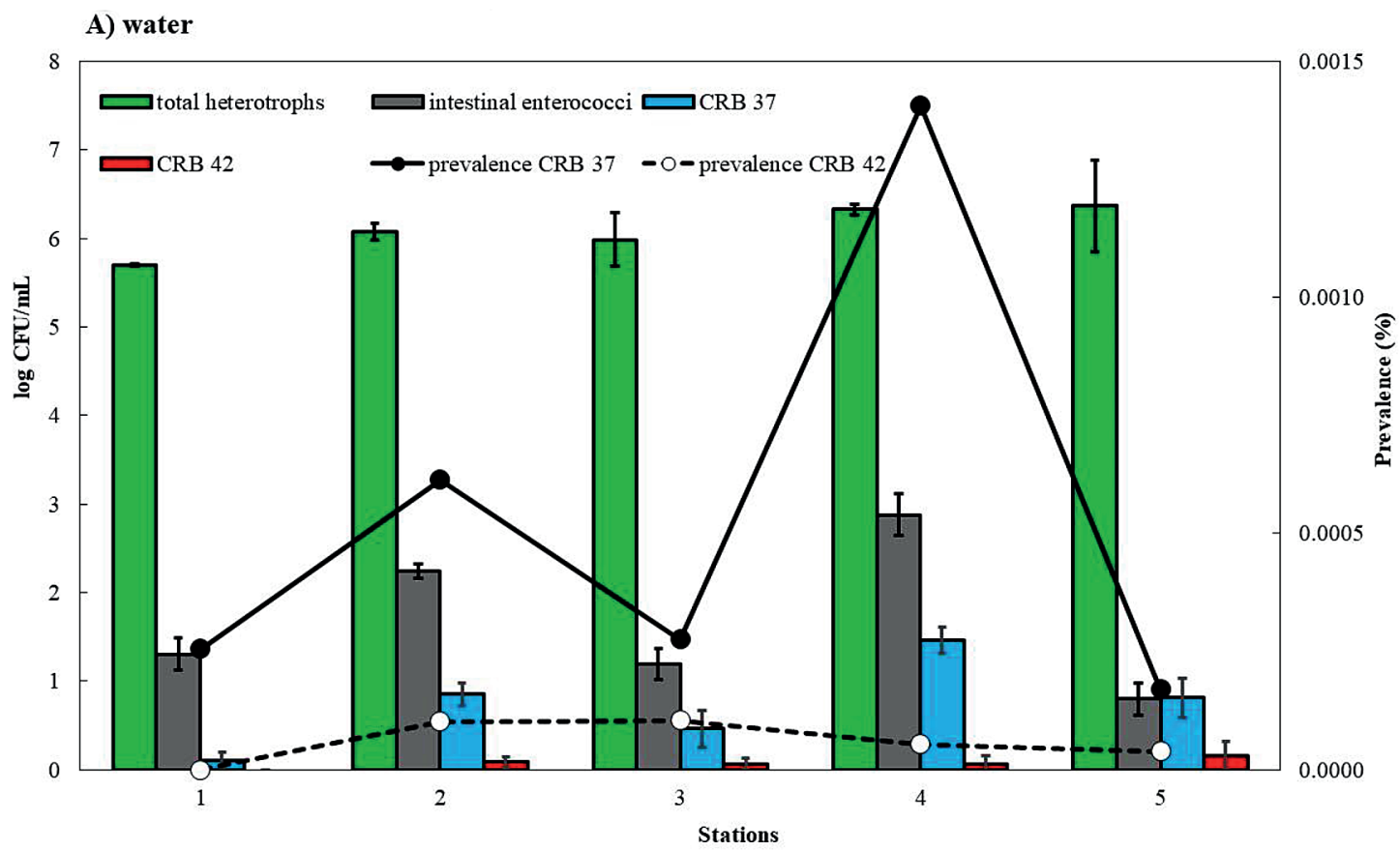

B) sediment

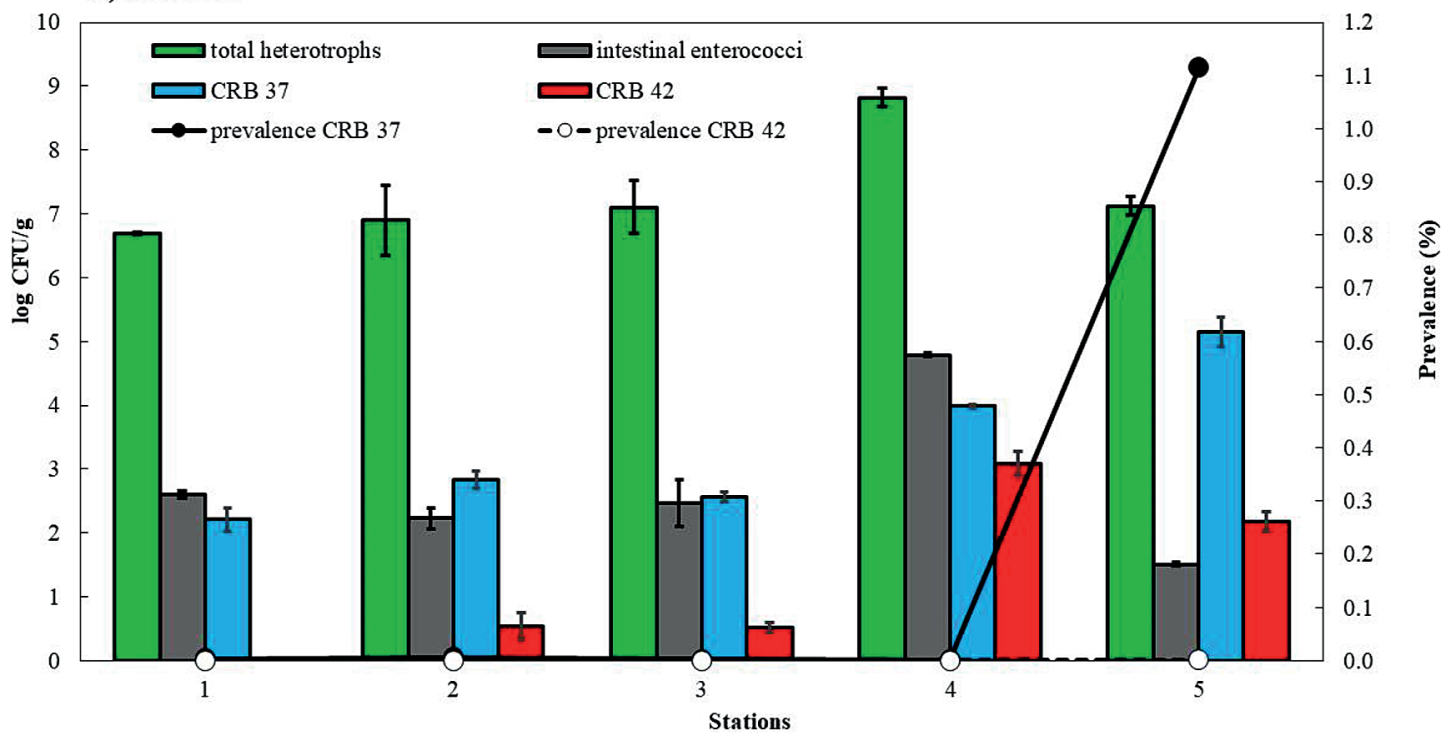

Figure 5

Numbers of bacteria per $1 \mathrm{~mL}$ of water (A) or $1 \mathrm{~g}$ of wet sediment $(B)$ at stations along the river. Mean values of triplicate measurements and standard deviations are presented. CRB37, CRB42 - carbapenem-resistant bacteria grown at 37 and $42^{\circ} \mathrm{C}$, respectively. Prevalence of CRB among total heterotrophic bacteria was calculated as (CFU ${ }_{C B B} /$ CFU ) $x 100$. 
as compared to corresponding CRB37, suggesting selection by an elevated temperature of incubation. CRB42 showed a significantly positive correlation with CRB37 $(r=0.821)$ and total heterotrophs $(r=0.782)$, but statistically insignificant correlation with intestinal enterococci $(r=0.322)$.

The list of CRB37 and CRB42 identified by MALDITOF MS is given in Table 4 . The CRB37 were represented by intrinsically resistant bacterial genera with only the genus Pseudomonas having acquired resistance to carbapenems (EUCAST, 2017). Among CRB42, dominance by genera with acquired resistance to carbapenems was found, with the exception of one Cupriavidus sp. and one Acidovorax temperans isolate. The cultivation at $42^{\circ} \mathrm{C}$ allowed the isolation of 9 carbapenem-resistant bacteria from the critical list by WHO (2107) (A. baumannii, K. pneumoniae and Klebsiella sp.), for which the confirmation of resistance to carbapenems was performed. All isolates were confirmed resistant to meropenem and imipenem according to EUCAST (2017) breakpoints for clinical isolates, with MIC values $\geq 16 \mathrm{mg} / \mathrm{L}$ (data not shown). Carbapenem-resistant $A$. baumannii and K. pneumoniae were isolated only from water at Station 5 , after discharge of wastewater from a general hospital. The MLST of carbapenemresistant $A$. baumannii isolate showed that it belongs to the international clonal lineage 2 (IC2) within the ST-195 by the Oxford scheme or ST-2 by the Pasteur scheme (data not shown).
Species with acquired resistance isolated from both water and sediment comprised 46/63 (73\%) after cultivation at $37^{\circ} \mathrm{C}$, and $35 / 37(95 \%)$ after cultivation at $42^{\circ} \mathrm{C}$. No bacterium was isolated at $42^{\circ} \mathrm{C}$ (CRB 42) from $50 \mathrm{~mL}$ of water or $1 \mathrm{~g}$ of sediment at Station 1.

\section{DISCUSSION}

The CRB37 were recently detected in river water in Portugal (Tacao et al., 2015), where the number of imipenem-resistant bacteria averaged $2.24 \mathrm{CFU} / \mathrm{mL}$. This concentration is comparable to the concentrations of CRB37 (1.29-7.37 CFU/mL) in the water flow of Krapinica River (Stations 1-3) and Krapina River receiving the general hospital wastewaters (Station 5). However, a much higher concentration of CRB37 (30 CFU/mL) was found in the creek water receiving the urban wastewater of the town Zabok (Station 4). This suggests that the concentration of CRB37 in river water is dependent on the proportion of wastewater that is discharged into the natural recipient.

The prevalence of CRB37 among total heterotrophic bacteria in analysed water samples $(0.0002-0.001 \%)$ was much lower than that reported (0.02-15.9\%) for untreated drinking water in Portugal (Henriques et al., 2012). The difference in the representation of CRB37 probably arises from different cultivation techniques used in analyses. In the study

\begin{tabular}{|c|c|c|c|}
\hline \multicolumn{4}{|c|}{$\begin{array}{l}\text { TABLE } 4 \\
\begin{array}{l}\text { List of bacteria with intrinsic and acquired* resistance to carbapenems according to EUCAST } \\
\text { criteria isolated after cultivation at } 37^{\circ} \mathrm{C} \text { and } 42^{\circ} \mathrm{C}\end{array}\end{array}$} \\
\hline Isolate & $\mathrm{N}$ isolated & Cultivation $\left({ }^{\circ} \mathrm{C}\right)$ & Water or sediment \\
\hline Acidovorax sp. & $1 / 1$ & 37 & Water/sediment \\
\hline Chryseobacterium sp. & 1 & 37 & Water \\
\hline Elizabethkingia sp. & 1 & 37 & Water \\
\hline Pseudomonas monteilii* & 7 & 37 & Sediment \\
\hline Pseudomonas oleovorans ${ }^{*}$ & 1 & 37 & Sediment \\
\hline Pseudomonas putida* & 17 & 37 & Sediment \\
\hline Pseudomonas veronii* & 1 & 37 & Water \\
\hline Pseudomonas sp. ${ }^{*}$ & 20 & 37 & Sediment \\
\hline Stenotrophomonas sp. & $2 / 4$ & 37 & Water/sediment \\
\hline Wautersiella sp. & $1 / 4$ & 37 & Water/sediment \\
\hline Wautersiella falsenii & 2 & 37 & Sediment \\
\hline Acidovorax temperans & 1 & 42 & Sediment \\
\hline Acinetobacter baumannii* & 1 & 42 & Water \\
\hline Burkholderia cenocepacia* & 2 & 42 & Water \\
\hline Burkholderia cepacia* & 1 & 42 & Water \\
\hline Burkholderia pyrrocinia* & 1 & 42 & Water \\
\hline Burkholderia sp.* & $10 / 2$ & 42 & Water/sediment \\
\hline Cupriavidus sp. & 1 & 42 & Water \\
\hline Enterococcus faecium ${ }^{*}$ & 5 & 42 & Water \\
\hline Klebsiella pneumoniae* & $6 / 1$ & 42 & Water/sediment \\
\hline Klebsiella sp.* ${ }^{*}$ & 1 & 42 & Water \\
\hline Ochrobactrum sp.* & 1 & 42 & Sediment \\
\hline Ochrobactrum intermedium ${ }^{*}$ & 2 & 42 & Sediment \\
\hline Pseudomonas otitidis* & 2 & 42 & Sediment \\
\hline
\end{tabular}


of Henriques et al. (2012) plates supplemented with $5 \mathrm{mg} / \mathrm{L}$ of imipenem were used, while isolates in this study had the MIC of imipenem above $16 \mathrm{mg} / \mathrm{L}$. The prevalence of CRB42 was always lower as compared to corresponding CRB37, but reached $0.0001 \%$ in water and $0.001 \%$ in sediment samples. This prevalence of clinically important CRB42 is considered to be very high, since a prevalence of $0.0006 \%$ is reported for urban sewage (Hrenovic et al., 2017b).

The positive correlation of CRB42 with CRB37 and total heterotrophs, but not with intestinal enterococci, suggests that entry of CRB42 into the riverine ecosystem is not necessarily connected to faecal pollution. The number of CRB42 is rather dependent on the type of pollution, and is associated with the discharge of wastewaters from different human and animal healthcare centres. Once in the environment, CRB42 behave as a part of the indigenous bacterial population. Similar behaviour of CRB42 has been reported for different stages of a secondary wastewater treatment plant (Hrenovic et al., 2017b).

A variety of environmental bacterial species of Proteobacteria, Firmicutes and Bacteroidetes possess intrinsic resistance to carbapenem (EFSA Panel on Biological Hazards, 2013). However, intrinsic resistance to carbapenems is not common among clinically important bacteria (Meletis, 2016). Clinical isolates of carbapenem-resistant bacteria possess acquired resistance and represent a global healthcare problem (Meletis, 2016). Previous studies (Hrenovic et al., 2016; Hrenovic et al., 2017a,b) have shown that cultivation of carbapenemresistant bacteria at 37 and $42^{\circ} \mathrm{C}$ is useful for distinguishing the presumably environmental (CRB37) from the presumably clinically important (CRB42) bacteria from environmental samples. In this study the presented diversity of species from river water and sediment confirmed that elevated temperature favours the isolation of clinically important CRB42.

The CRB37 were dominated by intrinsically resistant bacteria, while only Pseudomonas spp. had acquired resistance, which is in agreement with the diversity of carbapenemresistant bacteria from river water (Tacao et al., 2015) and untreated drinking water in Portugal (Henriques et al., 2012). Therefore, the CRB37 could generally be considered as part of the indigenous bacterial population of the riverine ecosystem.

The cultivation at $42^{\circ} \mathrm{C}$ allowed the isolation of a higher diversity of carbapenem-resistant bacteria, together with A. baumannii and Enterobacteriaceae, which are listed by WHO (2107). Carbapenem-resistant A. baumannii and $K$. pneumoniae were exclusively isolated from river water at Station 5 after discharge of the wastewater of the general hospital. The molecular characterization of carbapenemresistant A. baumannii isolate classified it as ST-195 inside IC2. This clonal lineage was also found to be predominant among clinical isolates of A. baumannii in European hospitals, including those of Croatia (Higgins et al., 2010; Seruga-Music et al., 2017). This indicates that the above-mentioned emerging hospital pathogens isolated from river water are presumably of clinical origin. They are discharged via untreated hospital wastewaters into natural water bodies. In natural water, $A$. baumannii is able to multiply and survive for more than 50 days (Hrenovic et al., 2016). Moreover, the statistical analyses showed that CRB42 behave in the environment as part of the indigenous bacterial population. This implies the need for disinfection of hospital wastewater prior to its discharge into the receiving natural water body, in order to avoid the consequent public-health threat.

Anthropogenic pressure in the form of discharge of untreated wastewaters causes bacteriological changes in the riverine ecosystem. The bacteriological changes are accompanied by an increase of silt and clay fractions, together with the concentration of heavy metals in sediments. The most worrying bacteriological change is the input of anthropogenically derived CRB42 from urban and especially hospital wastewaters. Dilution and auto-purification potential of the river was not evidenced through the river flow. This suggests that CRB42, once discharged in a riverine ecosystem, could be spread through the natural water bodies or accumulate in river sediments. The contaminated river water and sediment thus represent a potential source of clinically important CRB42.

\section{CONCLUSIONS}

Anthropogenic pressure, in the form of discharge of untreated wastewaters, cause the bacteriological changes of the riverine ecosystem. The bacteriological changes are accompanied by an increase in silt and clay fractions together with increased concentration of heavy metals in sediments. The input of wastewaters from human and animal healthcare centres results in the appearance of clinically important CRB42 in both river water and sediment. Emerging hospital pathogens A. baumannii and K. pneumoniae were confirmed among CRB42 only in river water sampled after the discharge of wastewater from a general hospital. Disinfection of hospital wastewater prior to its discharge into the natural environment should be performed in order to avoid both the propagation of CRB42 in the environment and consequent public-health threat.

\section{ACKNOWLEDGEMENTS}

This work has been supported by the Croatian Science Foundation (project no. IP-2014-09-5656). We thank B Hunjak, Croatian Institute of Public Health for enabling the use of the Vitek system.

\section{REFERENCES}

AKIBA M, SEKIZUKA T, YAMASHITA A, KURODA M, FUJII Y, MURATA M, LEE K, JOSHUA DI, BALAKRISHNA K, BAIRY I, SUBRAMANIAN K, KRISHNAN P, MUNUSWAMY $\mathrm{N}$, SINHA RK, IWATA T, KUSUMOTO M and GURUGE KS (2016) Distribution and relationships of antimicrobial resistance determinants among extended-spectrum-cephalosporin-resistant or carbapenem-resistant Escherichia coli isolates from rivers and sewage treatment plants in India. Antimicrob. Agents Chemother. 60 (5) 2972-2980. https://doi.org/10.1128/AAC.01950-15

APHA, AWWA and WEF (2005) Standard Methods for the Examination of Water and Wastewater (21 ${ }^{\text {st }}$ edn.). American Public Health Association, New York.

ASHBOLT NJ, GRABOW WO and SNOZZI M (2001) Indicators of microbial water quality. In: Fewtrell $\mathrm{F}$ and Bartram J (eds) Water Quality-Guidelines, Standards and Health Assessment of Risk and Risk Management for Water-Related Infectious Disease. World Health Organization, Geneva. 256-276.

AUBRON C, POIREL L, ASH RJ and NORDMANN P (2005) Carbapenemase-producing Enterobacteriaceae, US rivers. Emerg. Infect. Dis. 11 (1) 260-264. https://doi.org/10.3201/eid1102.030684

BRINDLEY GW and BROWN G (1980) Crystal Structures of Clay Minerals and their X-ray Identification. Mineralogical Society, London. $495 \mathrm{pp}$.

CHANDRAN SP, DIWAN V, TAMHANKAR AJ, JOSEPH BV, ROSALES-KLINTZ S, MUNDAYOOR S, LUNDBORG CS and MACADEN R (2014) Detection of carbapenem resistance genes and cephalosporin, and quinolone resistance genes along with oqxAB gene in Escherichia coli in hospital wastewater: a matter 
of concern. J. Appl. Microbiol. 117 (4) 984-995. https://doi. org/10.1111/jam.12591

CHOUCHANI C, MARRAKCHI R, HENRIQUES I and CORREIA A (2013) Occurrence of IMP-8, IMP-10, and IMP-13 metallo$\beta$-lactamases located on class 1 integrons and other extendedspectrum $\beta$-lactamases in bacterial isolates from Tunisian rivers. Scand. J. Infect. Dis. 45 (2) 95-103. https://doi.org/10.3109/0036554 8.2012 .717712

CAMS (2017) Antibiotic Resistance in Croatia, 2016. The Croatian Academy of Medical Sciences, Zagreb.

DEXTER C, MURRAY GL, PAULSEN IT and PELEG AY (2015) Community-acquired Acinetobacter baumannii: clinical characteristics, epidemiology and pathogenesis. Expert Rev. Anti. Infect. Ther. 13 (5) 567-573. https://doi.org/10.1586/14787210.2015.1025055

EFSA PANEL ON BIOLOGICAL HAZARDS (2013) Scientific opinion on carbapenem resistance in food animal ecosystems. EFSA J. 11 (12) 3501-3571. https://doi.org/10.2903/j.efsa.2013.3501

EUCAST (European Committee on Antimicrobial Susceptibility Testing) (2017) EUCAST Reading guide. Version 7.1. EUCAST, Vaxjo.

FERREIRA AE, MARCHETTI DP, DE OLIVEIRA LM, GUSATTI CS, FUENTEFRIA DB and CORCAO G (2011) Presence of OXA23-producing isolates of Acinetobacter baumannii in wastewater from hospitals in southern Brazil. Microb. Drug Resist. 17 (2) 221-227. https://doi.org/10.1089/mdr.2010.0013

GIRLICH D, POIREL L and NORDMANN P (2010) First isolation of the blaOXA-23 carbapenemase gene from an environmental Acinetobacter baumannii isolate. Antimicrob. Agents Chemother. 54 (1) 578-579. https://doi.org/10.1128/AAC.00861-09

HENRIQUES IS, ARAÚJO S, AZEVEDO JS, ALVES MS, CHOUCHANI C, PEREIRA A and CORREIA A (2012) Prevalence and diversity of carbapenem-resistant bacteria in untreated drinking water in Portugal. Microb. Drug Resist. 18 (5) 531-537. https://doi.org/10.1089/mdr.2012.0029

HIGGINS PG, DAMMHAYN C, HACKEL M and SEIFERT H (2010) Global spread of carbapenem-resistant Acinetobacter baumannii. J. Antimicrob. Chemother. 65 (2) 233-238. https://doi.org/10.1093/ jac/dkp428

HRENOVIC J, GOIC-BARISIC I, KAZAZIC S, KOVACIC A, GANJTO M and TONKIC M (2016) Carbapenem-resistant isolates of Acinetobacter baumannii in a municipal wastewater treatment plant, Croatia, 2014. Euro Surveill. 21 (15) 21-30. https://doi. org/10.2807/1560-7917.ES.2016.21.15.30195

HRENOVIC J, GANJTO M and GOIC-BARISIC I (2017a) Carbapenem-resistant bacteria in a secondary wastewater treatment plant. Water SA 43 (2) 186-191. https://doi.org/10.4314/ wsa.v43i2.02

HRENOVIC J, IVANKOVIC T, IVEKOVIC D, REPEC S, STIPANICEV D and GANJTO M (2017b) The fate of carbapenemresistant bacteria in a wastewater treatment plant. Water Res. 126 (1) 232-239. https://doi.org/10.1016/j.watres.2017.09.007

HRN ISO 7899-2 (2000) Water quality - detection and enumeration of intestinal enterococci, Part 2: membrane filtration method. Organization for Standardization, Geneva.

JACKSON ML (1979) Soil Chemical Analysis - Advanced Course. Soil Science Dept., University of Wisconsin, Madison, 250 pp.

KIEFFER N, POIREL L, BESSA LJ, BARBOSA-VASCONCELOS A, DA COSTA PM and NORDMANN P (2016) VIM-1, VIM-34, and IMP-8 carbapenemase-producing Escherichia coli strains recovered from a Portuguese river. Antimicrob. Agents Chemother. 60 (4) 2585-2586. https://doi.org/10.1128/AAC.02632-15

KITTINGER C, LIPP M, FOLLI B, KIRSCHNER A, BAUMERT R, GALLER H, GRISOLD AJ, LUXNER J, WEISSENBACHER M, FARNLEITNER AH and ZARFEL G (2016) Enterobacteriaceae isolated from the river Danube: antibiotic resistances, with a focus on the presence of ESBL and carbapenemases. PLoS One 11 (11) e0165820. https://doi.org/10.1371/journal.pone.0165820

LENART-BOROŃ A, WOLANIN A, JELONKIEWICZ E and ŻELAZNY M (2017) The effect of anthropogenic pressure shown by microbiological and chemical water quality indicators on the main rivers of Podhale, southern Poland. Environ. Sci. Pollut. Res. 24 (14) 12938-12948. https://doi.org/10.1007/s11356-017-8826-7 MARATHE NP, PAL C, GAIKWAD SS, JONSSON V,
KRISTIANSSON E and LARSSON DGJ (2017) Untreated urban waste contaminates Indian river sediments with resistance genes to last resort antibiotics. Water Res. 124 (1) 388-397. https://doi. org/10.1016/j.watres.2017.07.060

MELETIS G (2016) Carbapenem resistance: overview of the problem and future perspectives. Ther. Adv. Infect. Dis. 3 (1) 15-21. https:// doi.org/10.1177/2049936115621709

MOORE DM and REYNOLDS RC (1989) X-ray Diffraction and the Identification and Analysis of Clay Minerals. Oxford University Press, Oxford. $378 \mathrm{pp}$

OSTROUMOV SA (2006) Biomachinery for maintaining water quality and natural water self-purification in marine and estuarine systems: elements of a qualitative theory. Int. J. Ocean Oceanogr. 1 (1) 111-118.

PÁLL E, NICULAE M, KISS T, ŞANDRU CD and SPǏNU M (2013) Human impact on the microbiological water quality of the rivers. J. Med. Microbiol. 62 (11) 1635-1640. https://doi.org/10.1099/ jmm.0.055749-0

PIEDRA-CARRASCO N, FÀBREGA A, CALERO-CÁCERES W, CORNEJO-SÁNCHEZ T, BROWN-JAQUE M, MIR-CROS A, MUNIESA M and GONZÁLEZ-LÓPEZ JJ (2017) Carbapenemaseproducing enterobacteriaceae recovered from a Spanish river ecosystem. PLoS One 12 (4) e0175246. https://doi.org/10.1371/ journal.pone.0175246

SALOMONS W and FÖRSTNER U (1984) Metals in the Hydrocycle. Springer, Berlin. https://doi.org/10.1007/978-3-642-69325-0

SERUGA MUSIC M, HRENOVIC J, GOIC-BARISIC I, HUNJAK B, SKORIC D and IVANKOVIC T (2017) Emission of extensivelydrug-resistant Acinetobacter baumannii from hospital settings to the natural environment. J. Hosp. Infect. 96 (4) 323-327. https://doi. org/10.1016/j.jhin.2017.04.005

SOIL SCIENCE DIVISION STAFF (2017) Soil survey manual. United States Department of Agriculture. Agriculture Handbook No. 18, $603 \mathrm{pp}$.

SOUSA C, BOTELH J, SILVA L, GROSS F, NEMEC A, LOPES J and PEIXE L (2014) MALDI-TOF MS and chemometric based identification of the Acinetobacter calcoaceticus-Acinetobacter baumannii complex species. Int. J. Med. Microbiol. 304 (5-6) 669-677. https://doi.org/10.1016/j.ijmm.2014.04.014

ŚRODOŃ J (1984) X-ray powder diffraction identification of illitic materials. Clays Clay Miner. 32 (5) 337-349. https://doi.org/10.1346/ CCMN.1984.0320501

ŚRODOŃ J and EBERL DD (1984) Illite. In: Bailey SW (ed) Micas, Reviews in Mineralogy, 13. Mineralogical Society of America, Wisconsin. 495-544. https://doi.org/10.1515/9781501508820-016

TACÃO M, CORREIA A and HENRIQUES IS (2015) Low prevalence of carbapenem-resistant bacteria in river water: resistance is mostly related to intrinsic mechanisms. Microb. Drug Resist. 21 (5) 497-506. https://doi.org/10.1089/mdr.2015.0072

TASSIER A, CAMPBELL PCG and BISSON M (1979) Sequential extraction procedure for the speciation of particulate trace metals. Anal. Chem. 51 (7) 844-851. https://doi.org/10.1021/ac50043a017

WHO (World Health Organization) (2017) Global priority list of antibiotic-resistant bacteria to guide research,discovery, and development of new antibiotics. URL: http://www.who.int/ medicines/publications/WHO-PPL-Short_Summary_25Feb-ET_ NM_WHO.pdf?ua=1

ZHANG C, QIU S, WANG Y, QI L, HAO R, LIU X, SHI Y, HU X, AN D, LI Z, LI P, WANG L, CUI J, WANG P, HUANG L, KLENA JD and SONG H (2013) Higher isolation of NDM-1 producing Acinetobacter baumannii from the sewage of the hospitals in Beijing. PLoS ONE 8 (6) e64857. https://doi.org/10.1371/journal. pone.0064857

ZHANG X, LÜ X and ZONG Z (2012) Enterobacteriaceae producing the KPC-2 carbapenemase from hospital sewage. Diagn. Microbiol. Infect. Dis. 73 (2) 204-206. https://doi.org/10.1016/j. diagmicrobio.2012.02.007

ZURFLUH K, HÄCHLER H, NÜESCH-INDERBINEN M and STEPHAN R (2013) Characteristics of extended-spectrum $\beta$-lactamase- and carbapenemase-producing Enterobacteriaceae isolates from rivers and lakes in Switzerland. Appl. Environ. Microbiol. 79 (9) 3021-3026. https://doi.org/10.1128/AEM.00054-13 